\title{
INCREASING MOTIVATION THROUGH TASK-BASED LEARNING IN ASEAN STUDIES COURSE
}

\author{
Nguyen Thi Anh Thu* \\ Department of International Studies, College of Foreign Languages, Hue University, \\ 57 Nguyen Khoa Chiem, An Cuu, Hue, Vietnam
}

Received 30 December 2016

Revised 16 May 2017; Accepted 19 May 2017

\begin{abstract}
It is widely observed that students with low levels of motivation and engagement are one of the challenges for teachers in leading classes, especially in the major subject class. Lack of motivation among students not only has undesirable outcomes on students' academic performance but also negatively affects the teaching process. This research was conducted in order to increase students' motivation and engagement through a task-based learning environment in ASEAN Studies class in the department of International Studies, Hue University of Foreign Languages. The quantitative analysis used the data from a questionnaire to examine the impact of the task-based approach on students' level of motivation and engagement in ASEAN Studies class within 15 weeks. The study was conducted from September 3, 2016 through December 5, 2016 with 29 participating students in the second year at the Department of International Studies, Hue University of Foreign Languages. The findings indicated that students had the tendency to gain more motivation to participate in the class activities when tasks were used. Students' attitudes towards different tasks were also documented. Suggestions for teachers to make better use of this approach in teaching major subjects are discussed as well.
\end{abstract}

Keywords: task-based learning, task, motivation, international studies major, teaching

\section{Problem statement}

Teachers, for a long time, have been struggling to overcome the problem of low participation among students, especially in major subject class. It is not difficult to observe behaviors such as sleeping, engaging in digital gadgets, asking inappropriate questions, giving irrelevant answers, etc. among students with low levels of motivation. These attitudes are due to the fact that students are indifferent towards learning and participation (Aboudan, 2011). It is pointed out that when students find material and activities in class uninteresting, they are likely to get

* Tel.: 84-913935281

Email: anhthu.qth@gmail.com bored (Csikszentmihalyi, 1990, as cited in Aboudan, 2011). When boredom dominates, students are not stimulated to participate in the lesson (Caldwell, Darling, Payne, \& Dowdy, 1999, as cited in Aboudan, 2011). In the long term, the problem of low participation leads to serious impacts on students' academic performance and teaching process. Therefore, teacher researchers find a huge motivation to seek for a solution to this matter.

Task-based Learning (TBL) has been recommended to be utilized in order to increase the motivation among learners in English language classes as it contributes to create a favorable environment for arousing students' interest in the class material and motivation to participate in 
class activities (Ellis, 2003). In a task-based learning, students are given a task to solve. In this way, students can gain knowledge on the major subjects easily without concentrating on linguistic features during task implementation (Willis, 1996).

Inspired by its positive effects on the teaching and learning process, the teacher researcher makes use of the Task-based learning approach to promote motivation in the ASEAN Studies class during 15 weeks. This research was carried out in order to examine the impact of the taskbased learning approach on the level of participation among students.

\section{Theoretical framework}

This section provides a review of the literature on the fundamental concepts in motivating students to learn major subjects: motivation and task-based learning.

\subsection{Motivation}

In the research of Deci and Ryan (1985), motivation is classified into two different categories: intrinsic and extrinsic. While extrinsic motivation is linked with external factors such as rewards, intrinsic motivation refers to the internal incentive to fulfill learners' satisfaction, (Deci \& Ryan, 1985; Lepper \& Malone, 1987). This paper focuses on ways to heighten intrinsic motivation among learners in study major subject of ASEAN Studies.

Seven factors are pointed out to promote intrinsic motivation. In the first category of individual factors which refer to students' personal efforts, challenge, curiosity, control and fantasy are deciding motives. Gareau and Guo (2009) also agree that these individual factors are essential factors to engage students in class. Being engaged in class instructions, learners tend to go beyond the requirement of the instruction to show their knowledge, skills, competence and satisfaction (Gareau \& Guo, 2009). In the second category of interpersonal factors, three interpersonal factors such as competition, cooperation, and recognition play a significant role in cooperative learning when students are working with others in a team (Lepper and Malone, 1987). This conclusion is reaffirmed in the Self-Determination Theory developed by Deci \& Ryan (1985). Accordingly, learners' behaviors are initiated to fulfill three psychological needs, namely competence, autonomy, and relatedness. This means that students are motivated to participate when they feel they can interact efficiently in the environment, they can control the course of activities, and they feel a sense of belonging to the group.

In an effort to stimulate intrinsic motivation, Ellis (2003) suggests that the task-based learning is a new approach which tremendously benefits learners in all majors. Teachers who make use of tasks hold a belief that as long as students find motivations in their learning experience, students can find a way to complete any given tasks or achieve the desired goals (Brophy, 2005).

\subsection{Tasks-based Learning}

In the last years, task-based learning has been a vital instrument in language teaching in promoting communication and social interaction. In this model, language is acquired by having learners solve a problem or do a task without much concentrating on linguistic aspects. Language comes to learners along the solving-problem process since the language item used to complete tasks is similar as it is in daily life beyond the class (Willis, 1996). Hence, it is argued that task-based 
learning is an important approach for students to connect their knowledge to other tasks with communicative language (Ellis, 2003).

Tasks play a significant role in this learning and teaching model. Despite several suggested definitions of a task, this research adopts the definition by Willis (1996). According to Willis (1996), a task is "an activity where the target language is used by the learner for a communicative purpose (goal) in order to achieve an outcome" (p. 23). Specifically, a task is a class activity to use a target language to achieve a goal (Ellis, 2003). This also means the output of this learning experience is both language acquisition and specialized knowledge in the major subjects. This point inspires the teacher researcher to apply the model of Tasks-based learning in language teaching into teaching major subject in ASEAN Studies class.

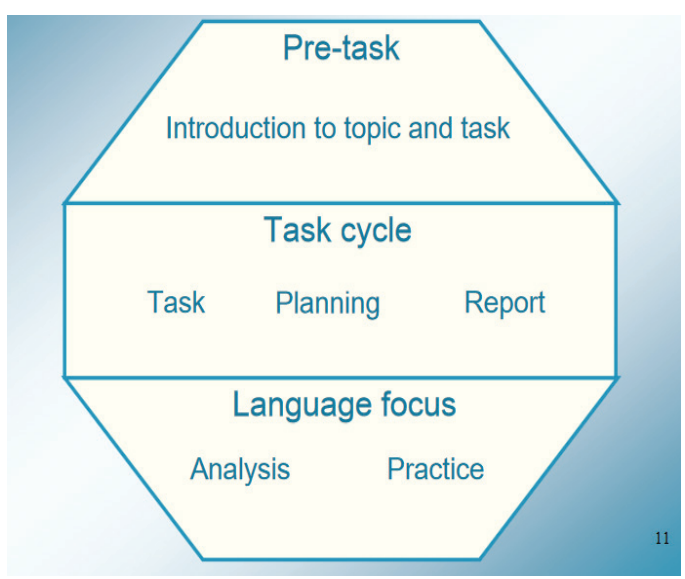

Figure 1. The TBL Framework

(Source: Jane Willis, a Framework for Taskbased learning, Longman ELT)

According to Willis (1996), a task consists of three stages: pre-task, task-cycle, and language focus. In the pre-task stage, students are given a topic and provided with necessary vocabulary by the teacher. In the task cycle, students work in pairs or in a small group to find the solution to a common question before making a presentation to the class. In the final stage, teacher will examine and analyze the specific language that students use in their report or their feedbacks about others' performance.

\section{Pre-task}

Teachers introduce the topic, provide useful vocabulary, and familiarize students with tasks instruction. Learners read the texts to understand the tasks

\section{TASK CYCLE}

\begin{tabular}{|c|c|c|}
\hline TASK & PLANNING & REPORT \\
\hline $\begin{array}{l}\text { Students work in pairs or small } \\
\text { groups to implement the task. } \\
\text { Students might feel free to try all } \\
\text { methods they can think of. } \\
\text { Teacher supervises the students } \\
\text { from a distance, promote students } \\
\text { to communicate with one another } \\
\text { instead of correcting their language. }\end{array}$ & $\begin{array}{l}\text { Students make a preparation to } \\
\text { present in front of class (orally or } \\
\text { writing) on the way they complete } \\
\text { the task, make a decision or achieve } \\
\text { in the end. As students give a report } \\
\text { in public, teachers will stand by their } \\
\text { side to provide any language support } \\
\text { if necessary. }\end{array}$ & $\begin{array}{l}\text { A few groups might spend } \\
\text { time to exchange their } \\
\text { findings or reports. } \\
\text { Teacher plays the role of } \\
\text { a chairperson to provide } \\
\text { feedbacks on students' } \\
\text { reports. }\end{array}$ \\
\hline
\end{tabular}

\section{LANGUAGE FOCUS}

\begin{tabular}{|c|c|}
\hline LANGUAGE ANALYSIS & PRACTICE \\
\hline $\begin{array}{c}\text { Students can have a reflection on the vocabulary they } \\
\text { used in their report. They can update some new words, } \\
\text { phrases they have learned in the field. }\end{array}$ & $\begin{array}{c}\text { Teachers analyze the language usage by } \\
\text { students in their report. }\end{array}$ \\
\hline
\end{tabular}


Another inspiring point is that any topic in any fields can be elaborated into any kind of tasks with the aim of promoting language usage. This generation can be done by adopting the typology for TBL framework which lists six tasks and their possible learning outcome (Willis, 1996:149). provided by teacher and to determine the learning outcomes which are finally achieved.

The research fundamentally offers a new approach to effectively use tasks in teaching a major subject in International Studies major. The research attempted to answer two questions:

\begin{tabular}{|c|c|c|c|}
\hline No. & Task Types & Skills involved & Task's outcomes \\
\hline 1 & Listing & Brainstorming, fact-finding & Completed list or draft mind map \\
\hline 2 & $\begin{array}{l}\text { Ordering \& } \\
\text { Sorting }\end{array}$ & $\begin{array}{l}\text { Sequencing, ranking, } \\
\text { categorizing, classifying }\end{array}$ & $\begin{array}{l}\text { Set out information sorted according to } \\
\text { specific criteria }\end{array}$ \\
\hline 3 & Comparing & $\begin{array}{l}\text { Matching, finding similarities \& } \\
\text { differences }\end{array}$ & Identification of similarities \& differences \\
\hline 4 & $\begin{array}{c}\text { Problem } \\
\text { solving }\end{array}$ & $\begin{array}{l}\text { Analyzing real problem, } \\
\text { analyzing hypothesis situation, } \\
\text { reasoning, decision-making }\end{array}$ & $\begin{array}{c}\text { Finding solutions to problems, which can be } \\
\text { then evaluated }\end{array}$ \\
\hline 5 & $\begin{array}{l}\text { Sharing } \\
\text { personal } \\
\text { experience }\end{array}$ & $\begin{array}{l}\text { Narrating, describing, exploring } \\
\text { and explaining attitude, reaction, } \\
\text { opinions }\end{array}$ & Exchanging opinions \& attitudes \\
\hline 6 & Creative tasks & & $\begin{array}{l}\text { End product - can be appreciated by wide } \\
\text { audience }\end{array}$ \\
\hline
\end{tabular}

A wide range of literature has been found on the effect of task-based learning in the field of teaching English as a foreign language (ELT). Researchers have demonstrated that TBL contribute to enhancing students' motivation. Nevertheless, there is limited knowledge on the application of this model in teaching major subjects in International Studies. Therefore, this research aimed to utilize the task-based approach to engage students in learning academic subjects like ASEAN Studies.

\section{Research objectives and questions}

The objective of the study is to investigate the impacts of tasks on motivating students to engage more in ASEAN Studies class. Specifically, the research investigates learners' attitudes to the advantages or disadvantages of particular tasks in Task- Based Learning
1. To what extent do tasks motivate non-English majors to engage and participate in the class?

2. What are students' attitudes towards the use of particular tasks in task-based learning in ASEAN Studies Course?

\section{Research methodology}

\subsection{Procedure}

The tools utilized were a Questionnaire on intrinsic motivation to investigate students' perception of the impacts of tasks used in ASEAN Studies Class. This tool was used to document evidence of how tasks enhance students' motivation and engagement. Data was collected during 15-week period from September 5, 2016 through December 5, 2016. The questionnaire created on a Google form was documented online. The final 
results were saved on a Google spreadsheet. There are ten questions with various choices for responses in the questionnaire. In the first part, students were provided with multiplechoice questions to explore whether the utility of tasks motivate them to engage in the class. In the second section on particular tasks, students were requested to come up with their own responses to explain their preference on a certain tasks that they had worked in ASEAN Studies class (see Appendix A). A task-based lesson which was generated based on Willis' (1996) framework for TBL on a topic of ASEAN Studies was also developed (see Appendix B).

\subsection{Participants}

29 students in International Studies major at the Department of International Studies, Hue University of Foreign Languages participated in this study. Their age range is 21. Most students had learned English as a required subject for six years in high school and in the first three years in university. The class met once a week for ninety minutes.

\section{Research findings and discussion}

Figure 2 shows students' responses to the question, "How likely are teachers to provide class activities that are related to your interests?" According to Figure 2, 44.8\% of students believe that the tasks provided in ASEAN class are very likely related to their interests, $31 \%$ of students feel that the tasks are most likely related to their interest, $24.1 \%$ of the students feel the tasks are somewhat likely related to their interest. It is a positive sign that no students perceive the tasks are not related to their interest.

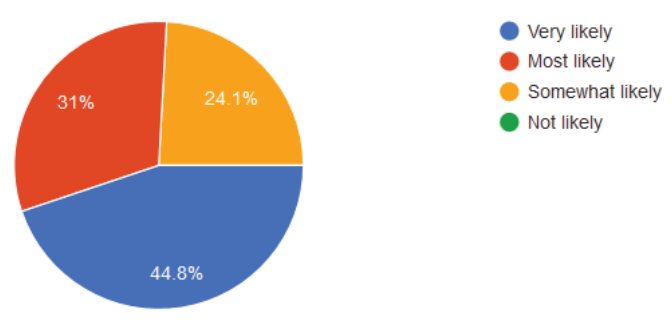

Figure 2. Students' responses to the question "How likely are teachers to provide class activities that are related to your interests?"

Figure 3 shows the respondents' responses to the question "How likely are you to engage in classroom activities when tasks are used?" According to Figure 3, 75.9\% of students are more engaged in the lesson with the utility of different kinds of tasks. On the other hand, $24.1 \%$ students are demotivated to participate in the class activities. It is a favorable conclusion that no students asserted that tasks make no difference in their engagement in classroom activities.

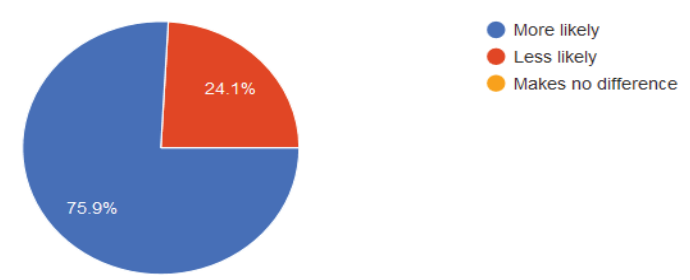

Figure 3. Students' responses to the question "How likely are you to engage in classroom activities when tasks are used?"

Figure 4 presents students' evaluation on the factors that make them interested in tasks. $58.6 \%$ of students do not feel fears when giving wrong answers in front of peers or expressing unpopular answers. Likewise, $58.6 \%$ students feel confident because they can show their abilities in front of class through 
several tasks. $55.2 \%$ of students are excited to join in a competition with other teams. $51.7 \%$ of students rated for the facts that they are excited to join in a various learning atmosphere. $48.3 \%$ students are motivated as they collaborate and communicate with other team members to achieve a common goal. $44.8 \%$ students consider the task as a challenge and want to overcome it. $31 \%$ of respondents claimed that the instruction is interesting and worthy of attention. Only $20.7 \%$ of students are encouraged that the tasks are do-able and they can fulfill it.

Obviously, among the four factors in intrinsic motivation mentioned in the theoretical framework - attention, relevance, confidence, and satisfaction, confidence is the most recognized incentive that students perceive in using tasks in ASEAN Studies class. Besides the confidence factors, satisfaction is also important motives for students to engage themselves in class activities. Attention comes next in their importance to students. Few students consider relevance much important to them in their learning experience. However, interpersonal factors are claimed to be more important than three other individual factors, except confidence factor. Particularly, recognition is fundamentally leading factors among the three, with competition and cooperation are rated equally important in students' perception.
Notes. The checkboxes for students are provided in full as follows:

1. Students consider the task as a challenge and feel excited to overcome it

2. Students perceive the instruction is interesting and worthy of attention

3. Student feel the tasks/questions are do-able and they can fulfill it

4. Student feel excited about being in the various learning atmosphere

5. Students are motivated to join in a competition with other groups

6. Students communicate and collaborate with other team members to work for a common goal during activities

7. Student do not fear giving wrong answers in front of peers or expressing unpopular opinions

8. Learners feel confident because they can show their capability in front of class

The data in Figure 5 demonstrates learners' preference to the different tasks used in ASEAN Studies class. Data indicates that there are obvious differences among learners' choices of their favorite tasks. Problem solving (including solving a real problem and decision-making) is ranked the highest with $44.8 \%$ choosing this task as their favorable one while the results for other tasks were on lower profile. Creative tasks and comparing

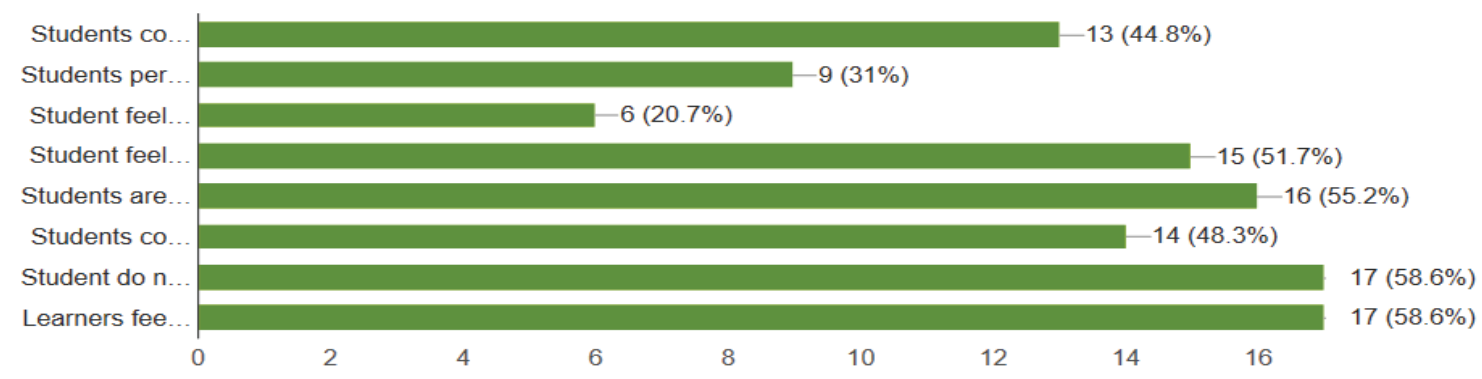

Figure 4. Students' responses to the question "Check the reasons that make you NOT bored with the ASEAN Studies class. Check all that apply." 
was both chosen by $41.4 \%$ of students while listing, and sharing stories was voted by $37.9 \%$ and $31 \%$ respectively. Very few students $(10.3 \%)$ favored ordering tasks in the class activities. To grasp a better understanding of the impacts of each task on learners, the questions from 5-10 were given in the Questionnaire and reported in Figures 6, 7, 9, $12,17 \& 18$. learners so they do not feel bored. On the other hand, more students prefer fact-finding since it helps students improve skimming and scanning in reading skills, and understand the topic in a profound way; it is easy to find the information in the articles without much thinking; and it stimulates learner to read the articles at home to have a better preparation.

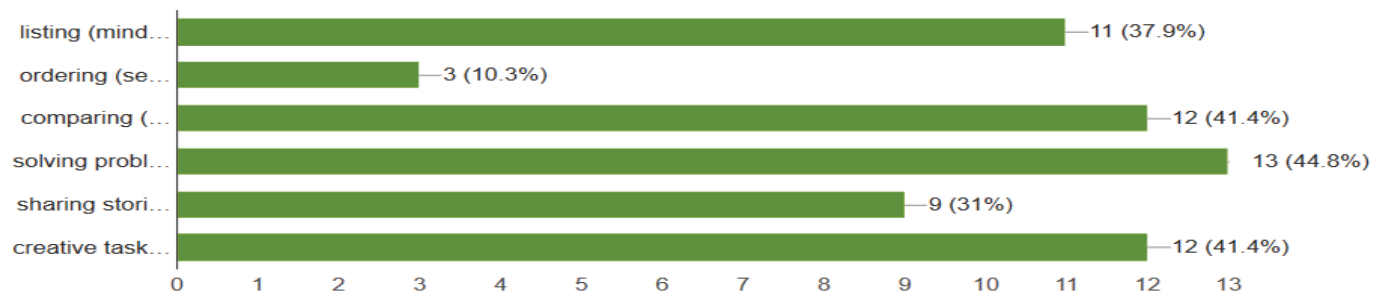

Figure 5. Students' reponse to the question "What task do you enjoy using in ASEAN Studies class? Check all that apply."

Notes. The checkboxes for students are provided in full as follows:

1. Listing (mindmap, fact-finding)

2. Ordering (sequencing, classifying)

3. Comparing (matching, finding similarities and differences)

4. Solving problem (solving a real problem, decision-making)

5. Sharing stories (describing, explaining reaction \& attitudes)

6. Creative tasks (brainstorming, factfinding, comparing, problem solving)

Figure 6 outlines learners' perception on listing tasks. Specifically, among the two tasks - mind-map and fact-finding, while $51.7 \%$ of respondents enjoyed finding facts in the reading articles while $48.3 \%$ of students prefer developing a mind-map. Learners also stressed the importance of each tasks for them. Mind-map was rated useful as it is visual, lively, logical, and easy to understand the topic; and it promotes critical thinking among

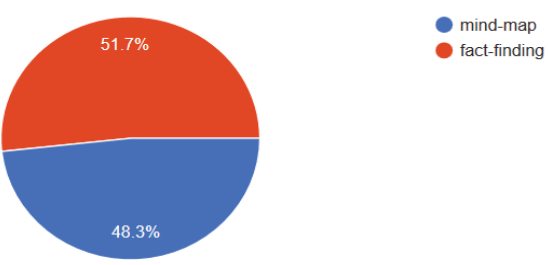

Figure 6. Students' response to the question "In terms of listing task, which task interests you?"

In terms of ordering tasks, only a minority of students $(20.7 \%)$ have a positive attitude of sequencing task (see Figure 7). These students claim that this task helps students remember the timeline of events which occurred in ASEAN history; thus they can understand and remember well ASEAN's achievement and failure at a particular period of time. A majority of students $(79.3 \%)$ of respondents emphasized the importance of this classifying task as a tool to deeply understand and well remember the lesson by realizing the different facets of ASEAN's achievements, and promote 
her/his critical thinking as well as decisiveness (Figure 8).

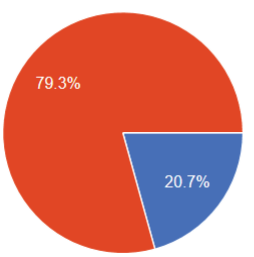

sequencing

classifying

Figure 7. Students' response to the question

"In terms of ordering task, which task interests you?"

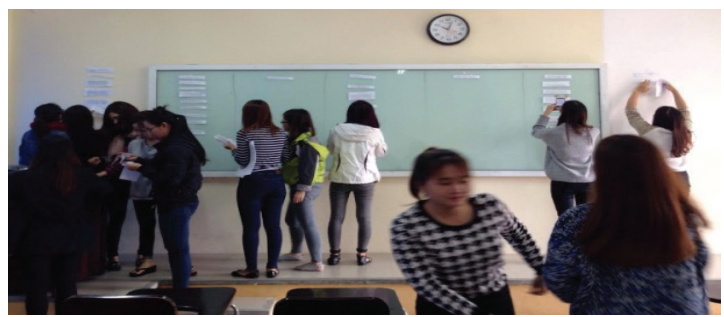

Figure 8. Students classifying the given information on ASEAN's achievement into three categories - political, economic, and socio-cultural achievements

The distribution of students' attitudes towards comparing tasks (including matching, and finding similarities and differences) can be found in Figure 9. It is presented that these two tasks were favored by students, with $37.9 \%$ of students chose matching, and $62.1 \%$ of respondents went for finding differences and similarities. The former is reported to be easier to fulfill than the latter because students can guess the answers. Besides, matching task enables them to realize the connection between main ideas and supporting ideas (e.g. events), so they can improve analysis skill when they approach a problem. For some students, matching makes learning atmosphere more exciting and learners become more active (Figures $10 \& 11$ ). With regards of finding similarities and differences, one of the students claimed that "In my opinion, I really like finding similarities and differences more. Because I have to read all carefully to find out the similarities and differences so I can remember a lot of information and knowledge". Besides, students like this task because it helps them understand the nature of the problem by comparing and contrasting two issues; therefore, students find it easier to remember the main knowledge of related to the topic. Students are stimulated to explore the topic more after completing this task. An additional reason is that this task is quite challenging to students, so they have to read articles carefully to find the answer, so they can remember the related knowledge.

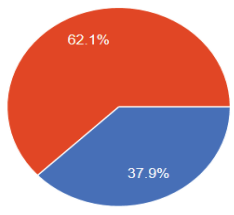

- matching

finding similarities and differences

Figure 9. Students' response to the question "In terms of comparing task, which task interests you?"
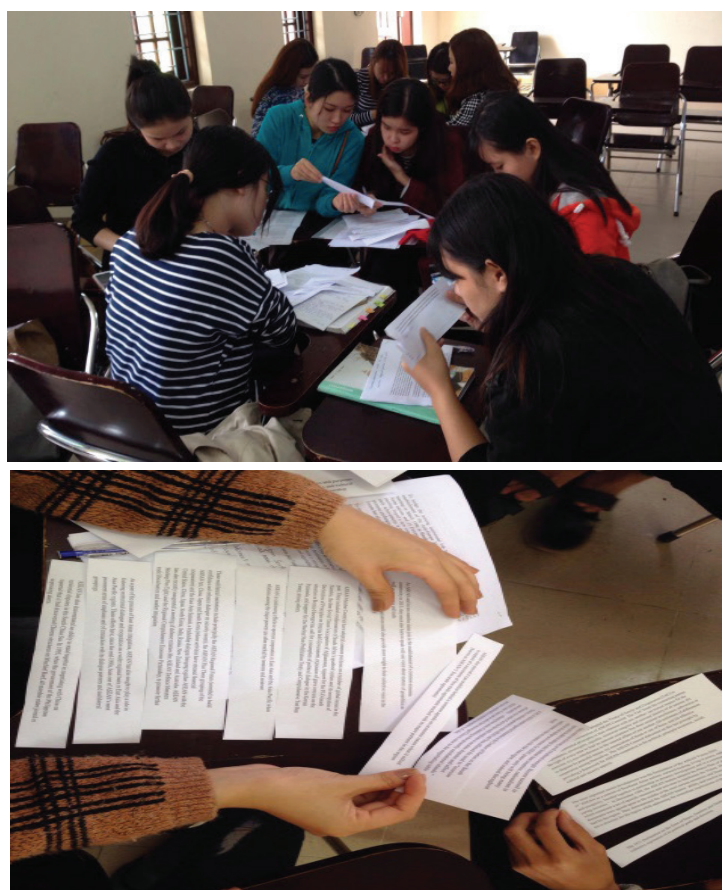

Figures $10 \& 11$. Students working to match the viewpoints on the Permanent Court of Arbitrary (PCA)'s ruling on South China Sea with correct ASEAN member states 
The component of problem solving tasks includes analyzing real or hypothetical situations, reasoning and decision making. In this survey, only analytical and decision-making tasks were adopted. As shown in Figure 12, a vast majority of students of $65.5 \%$ were fond of analyzing a real problem task while $34.5 \%$ enjoyed decisionmaking. In the former task, students are likely to utilize their critical thinking to pick up the details of the problem, so they tend to understand the issue deeper and remember the problem well. Learners are also interested in analyzing the problem as this task enables them to realize related issues surrounding the focal topic which they often ignore.

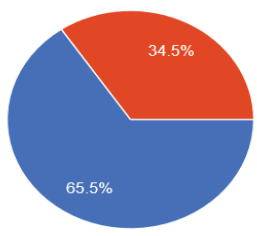

analyzing a real problem decision-making

Figure 12. "In terms of problem solving task, which task interests you?"
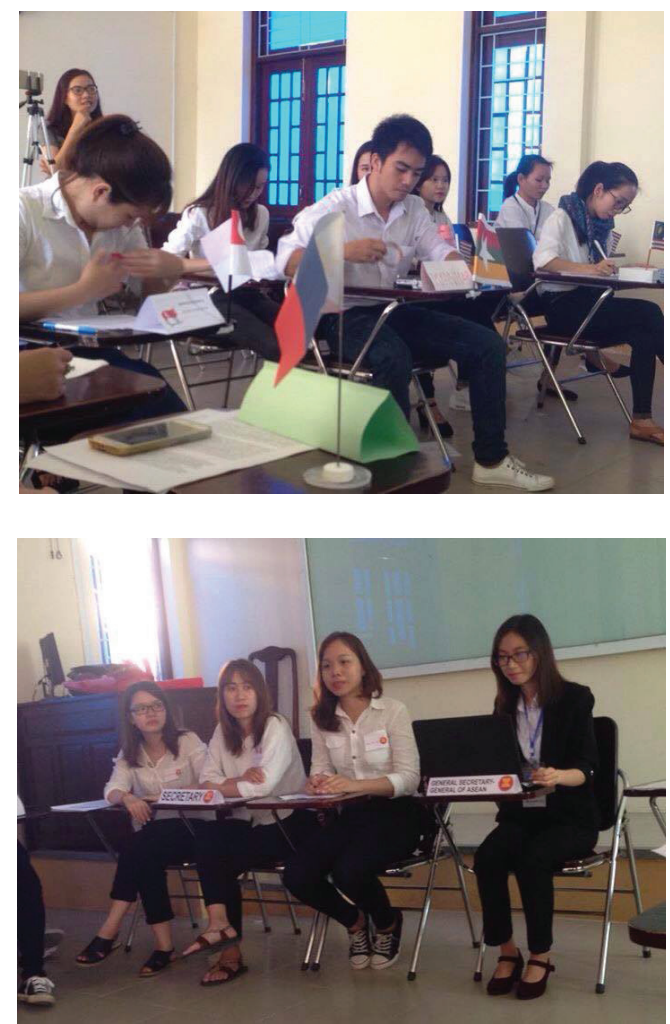
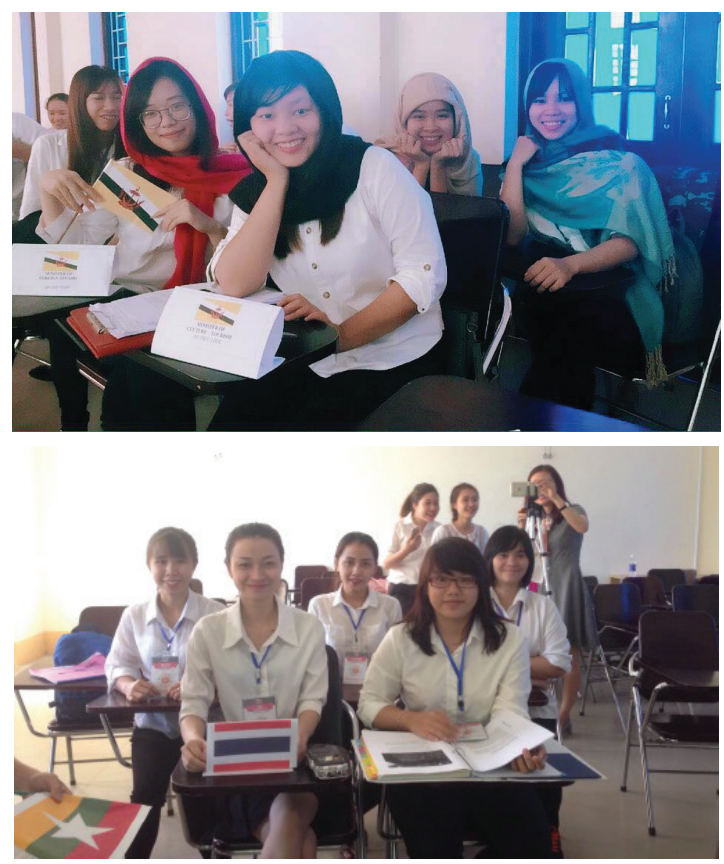

Figures 13, 14, $15 \& 16$. Students taking the role of Representatives of ASEAN member states at ASEAN Summit

Besides, students felt motivated in this task as they are allowed to express their own ideas about the problem. One student mentioned that when she played the role of the Minister of an ASEAN state to join in ASEAN Summit, she had to put herself into the shoes of the leaders to make a decision, in this way, she could show her ability and knowledge in the field of economics, education, or security (Figures 13, 14, 15 \& 16).

Concerning decision-making task, students claimed that they were motivated to think quickly to seek for optimal answer, so they became more decisive in their study. Some students find this task useful because it requires creativity from learners since they have to think seriously about the problem before making a decision on the possible solution, so this is the best way for them to have a closer look at the problem. For others, decision-making task was preferable because it provides them opportunities to express their own knowledge about the problem and show their abilities of problem-solving without a fear of making mistakes (Figure 12). 
In the TBL framework, sharing personal experience task involves narrating, describing, exploring \& explaining attitudes and expressing opinions and reactions. However, the task of sharing personal experience was not documented in this survey. This is a limitation in applying Willis's TBL framework into ASEAN Studies class. This can be explained by the fact that studying regional events in ASEAN is far from personal experiences. Therefore, teachers found it difficult to create a task to encourage students to share their personal experiences which should be related to the discussion topic such as refugee crisis, ASEAN relations with the superpowers, etc. in ASEAN class.

Figure 17 illustrates students' attitude towards personal experience sharing task in ASEAN Studies class. 72.4\% students prefer explaining their attitude to describing their experience which was chosen by $27.6 \%$. Those who were fond of the former believe that this task allows them to understand their feeling through the related activity, therefore, understand more the discussed problem. Besides, others felt excited to listen to their peers' sharing about their reflection about the same activity they joined in, especially when their reflections were creative and interesting. In this way, the problem became clearer to them and easier to understand. Apparently, giving explanation about their attitude and reaction in a class activity to understand a topic is more interesting to students than simply giving a description of their experience.

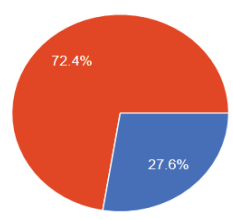

describing

explaining reactions \& attitudes

Figure 17. Students' reponse to the question "In terms of sharing personal experience task, which task interests you?"
Figure 18 illustrates learner's viewpoint on different tasks used in a creative task. It can be seen from students have a more favorable attitude towards problem-solving (55.2\%) and brainstorming (44.8\%) than comparing (31\%) and fact-finding (24.1\%). A majority of students agreed that being allowed to give their own solution and decision to a problem made them more creative, excited and engaging in the class. A large number of students prefer brainstorming tasks because it has no rules and students can gain independence to come up with their own answer in a comfortable learning atmosphere. They also felt motivated as brainstorming required them to think critically about the problem and deepen their understanding of the problem.

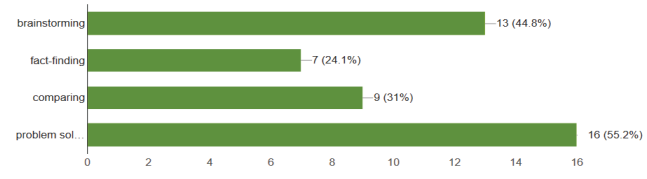

Figure 18. Students' response to the question "In terms of creative task, which task interests you? Check all that apply."

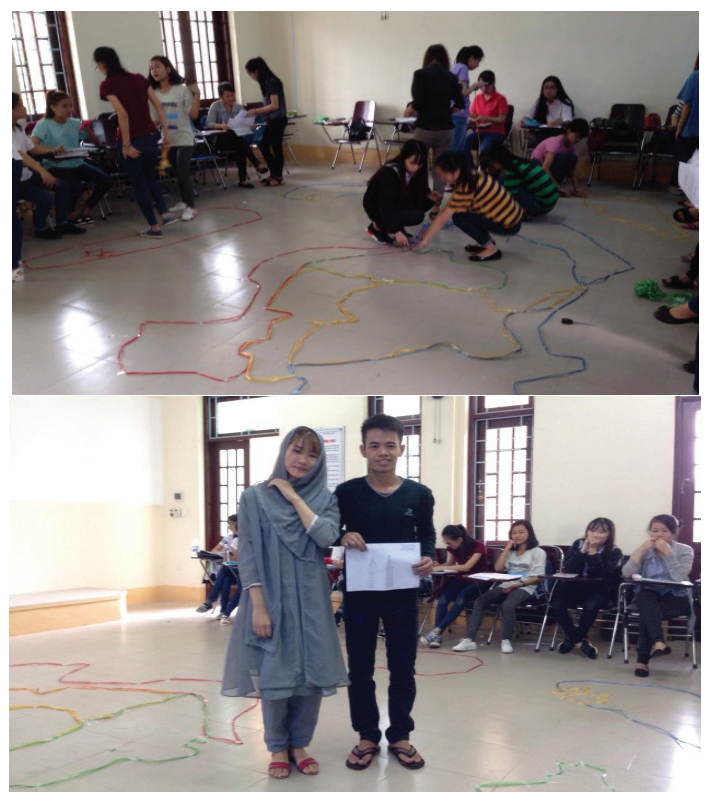

Figures $19 \& 20$. Students identifying state territories in ASEAN and presenting their culture to the class 


\section{Conclusion}

The study provides students' evaluation of the TBL on students in learning a major subject like ASEAN Studies. The finding highlights that TBL is useful in increasing students' motivation and engagement in ASEAN Studies class. Among the factors that increase students' motivation which are mentioned in the Literature Review, except the factor of confidence, the three interpersonal elements (recognition, competition and cooperation) are more important than personal factors (fantasy, challenge, curiosity, and control). This point is important in a way that it encourages teachers to organize group work to solve different tasks in their class.

Among several skills that are suggested by Willis (1996), students in ASEAN Studies class are interested in particular skills which are reflected as below. The result might be useful to provide teachers with suggestions on suitable tasks to fit students' interest.

1. task of ordering - classifying $-79.3 \%$ (Figure 7),

2. task of sharing personal experience explain attitude and reaction $-72.4 \%$ (Figure 17)

3. task of problem-solving - analyzing a real situation $-65.5 \%$ (Figure 12 ),

4. task of comparing-finding the differences and similarities $-62.1 \%$ (Figure 9),

5. creative task - problem-solving $-55.2 \%$ (Figure 18),

6. task of listing - fact-finding - 51.7\% (Figure 6).

\section{References}

Aboudan, R. (2011). "Engage them, don't enrage them - student voices and what it takes to participate". English Language Teaching, Vol. 4, No.1, pp. 128134. Available through $<$ http://www.ccsenet.org/ elt $>$, Accessed 10/12/2016 10:50

Brophy, J. (2005). Motivating students to learn (2nd ed.). Mahwah, NJ: Lawrence Erlbaum.
Bygate, M., Skehan, P., \& Swain, M. (2001). Researching pedagogic language learning, teaching and testing. Harlow, England: Longman.de la Fuente, M. J. (2006). Classroom L2 vocabulary acquisition: Investigating the role of pedagogical tasks and formfocused instruction. Language Teaching Research, Vol. 10, No. 3, pp. 263-295. Available from <http:// dx.doi.org/10.1191/13621688061r196oa>,_Accessed 10/12/2016 12:15

Deci, E. L., \& Ryan, R. M. (1985). Intrinsic motivation and self-determination in human behavior. New York, NY: Plenum Press.

Ellis, R. Task-Based Learning and Teaching. (2003). Oxford University Press.

Filer, D. (2010). Everyone's answering: Using technology to increase classroom participation. Nursing Education Perspectives, Vol. 31, No. 4, pp. 247-250. Available through $<$ http://www.nlnjournal. org/>, Accessed 10/12/2016 13:20

Gardner, R. C., \& Lambert, W. E. (1972). Attitudes and motivation in second language learning. Rowley, MA: Newbury House.

Gareau, S., \& Guo, R. (2009). "All work and no play" reconsidered: The use of games to promote motivation and engagement in instruction. International Journal for the Scholarship of Teaching and Learning, Vol. 3, No. 2, pp. 1-11. Available through $<$ http://dspaceprod.georgiasouthern. edu:8080/xmlui/handle/10518/3638>, Accessed 11/12/2016 15:30

Lepper, M. R., \& Malone, T. W. (1987). Intrinsic motivation and instructional effectiveness in computer-based education. In R. E. Snow \& M. J. Farr (Eds.), Aptitude, learning and instruction, Vol. 3: Conative and affective process analyses (pp. 255267). Hillsdale, NJ: Lawrence Erlbaum

Nunan, D. (2004). Task-based language teaching. Cambridge, England: Cambridge University Press

Simpson, A. Task-Based Learning. Available through $<$ http://www.esl-lounge.com/adamsimpson- taskbased-learning.shtml>, Accessed 9/12/2016 9:15

Willis, J. (1996). A Framework for Task-Based Learning. London: Longman. Pearson Education Limited 


\title{
THÚC ĐẨY SỬ THAM GIA CỦA SINH VIÊN TRONG GIẢNG DẠY MÔN NGHIÊN CÚUU ASEAN BĂNG PHƯỚNG PHÁP HỌC TẬP DỰA TRÊN NHIỆM VỤ
}

\author{
Nguyễn Thị Anh Thư \\ Khoa Quốc tế học, Trường Đại học Ngoại ngũu, Đại học Huế, \\ 57 Nguyễn Khoa Chiêm, phuờng An Cựu, TP. Huế, Việt Nam
}

Tóm tắt: Một trong những khó khăn mà đa phần các giảng viên đều phải đối mặt trong việc giảng dạy các môn chuyên ngành Quốc tế học là người học thường thụ động và lười tham gia vào bài học. Điều này không chỉ tác động tiêu cực đến kết quả học tập của sinh viên mà còn ảnh hưởng đến quá trình dạy học các môn chuyên ngành của giáo viên. Nghiên cứu này được thực hiện nhằm xem xét tính hiệu quả của phương pháp học tập dựa trên nhiệm vụ trong việc thúc đẩy động lực học tập bên trong cho sinh viên, từ đó họ sẽ tích cực tham gia vào bài giảng trong môn ASEAN học tại Khoa Quốc tế học, Trường Đại học Ngoại ngữ, Đại học Huế. Dữ liệu được thu thập từ bảng hỏi để đánh giá nhận thức của người học về tác động của phương pháp dạy học này đến động lực học tập của họ. Nghiên cứu được tiến hành với 29 sinh viên năm thứ 4 tại Khoa Quốc tế học, Trường Đại học Ngoại ngữ, Đại học Huế trong 15 tuần dạy học, từ 3/9/2016 đến 12/12/2016. Nghiên cứu chỉ ra rằng người học đã có thêm nhiều động lực để tham gia vào bài học khi giáo viên đưa ra các nhiệm vụ để sinh viên giải quyết. Dựa trên kết quả thu được từ thái độ của sinh viên đối với từng nhiệm vụ khác nhau trong các lớp học ASEAN học, bài nghiên cứu sẽ cung cấp nhiều gợi ý cho các giáo viên để có thể phát huy hơn nữa phương pháp này nhằm thúc đẩy động lực cho người học.

Từ khóa: phương pháp học tập dựa trên nhiệm vụ, nhiệm vụ, động lực, giảng dạy môn chuyên ngành Quốc tế học 


\section{APPENDIX A: QUESTIONNAIRE "Increasing Motivation in ASEAN Studies Class"}

Please check your response to the following statements. Write any additional comments in the notes section. This survey is anonymous. Please do not put your name on it.

1. How likely are teachers to provide class activities that are related to your interests?
$\square$ Very likely
$\square$ Most likely $\square$ Somewhat likely
$\square$ Not likely

2. How likely are you to engage in classroom activities when tasks are used?

$\square$ More likely $\square$ Less likely $\square$ Makes no difference

\section{Check the reasons that make you NOT bored with the ASEAN Studies class. Check all} that apply.

Students consider the task as a challenge and feel excited to overcome it

$\square$ Students perceive the instruction is interesting and worthy of attention

$\square$ Student feel the tasks/questions are do-able and they can fulfill it

$\square$ Student feel excited about being in the various learning atmosphere

$\square$ Students are motivated to join in a competition with other groups

$\square$ Students communicate and collaborate with other team members to work for a common goal during activities

$\square$ Student do not fear giving wrong answers in front of peers or expressing unpopular opinions.

$\square$ Learners feel confident because they can show their capability in front of class

4. What task do you enjoy using in ASEAN Studies class? Check all that apply.

$\square$ listing (mind-map, fact-finding)

$\square$ ordering (sequencing, classifying)

$\square$ comparing (matching, finding similarities and differences)

$\square$ solving problem (analyzing a real problem, decision-making)

$\square$ sharing stories (describing, explaining reactions \& attitudes)

$\square$ creative task (brainstorm, fact-finding, comparing, problem solving)

5a. In terms of listing task, which task do you prefer? Check all that apply.

$\square$ mind-map $\square$ fact-finding

$5 \mathrm{~b}$. Why is this task is preferable to you?

6a. In terms of ordering task, which task do you prefer? Check all that apply. $\square$ sequencing $\square$ classifying

6b. Why is this task is preferable to you? 
7a. In terms of comparing task, which task do you prefer? Check all that apply.

$\square$ matching $\square$ finding similarities and differences

7b. Why is this task is preferable to you?

8a. In terms of problem solving task, which task do you prefer? Check all that apply.

$\square$ analyzing a real problem $\square$ decision-making

$8 \mathrm{~b}$. Why is this task is preferable to you?

9a. In terms of sharing personal experience task, which task do you prefer? Check all that apply.

$\square$ describing $\square$ explaining reactions \& attitudes

9b. Why is this task is preferable to you?

10a. In terms of creative task, which task do you prefer? Check all that apply.

brainstorming

fact-finding

comparing

problem solving

$10 \mathrm{~b}$. Why is this task is preferable to you?

Thanks for your responses to this questionnaire!

\section{APPENDIX B}

A Task-Based Lesson in ASEAN Studies Course

Topic: Achievement of ASEAN

Level: 4-year university student

Time: 90 minutes

Objectives: By the end of the class, students can grasp a good understanding of ASEAN's achievement in all areas in the last 40 years since its establishment.

Preparation: cue cards of significant events in ASEAN

\begin{tabular}{|c|c|c|c|}
\hline Stages & Aim & Procedure & Interaction \\
\hline & \multirow{3}{*}{$\begin{array}{l}\text { Ss are introduced to the } \\
\text { context before ASEAN } \\
\text { was established } \\
\text { (Activity 1) }\end{array}$} & Ss join the buffalo-farmer game. & \multirow[b]{3}{*}{ Individual } \\
\hline & & $\begin{array}{l}\text { T gives Ss questions to brainstorm the connection } \\
\text { between the game and relations in Southeast Asia } \\
\text { region then. } \\
\text { Ss give individual reflective answer about }\end{array}$ & \\
\hline Pre-task & & $\begin{array}{l}\text { Ss give individual reflective answer on the relation } \\
\text { between the buffalo and farmer; and make a } \\
\text { connection to the relations among regional states } \\
\text { then. }\end{array}$ & \\
\hline
\end{tabular}




\begin{tabular}{|c|c|c|c|}
\hline $\begin{array}{l}\text { Task } \\
\text { Cycle } \\
\text { Task 1 }\end{array}$ & $\begin{array}{l}\text { Ss classify the given } \\
\text { events }\end{array}$ & $\begin{array}{l}\text { Ss read the article before class and categorizing } \\
\text { the ASEAN significant events into corresponding } \\
\text { dimension of cooperation }\end{array}$ & Group \\
\hline Planning & $\begin{array}{l}\text { Ss match events } \\
\text { with corresponding } \\
\text { dimension. }\end{array}$ & $\begin{array}{l}\text { Ss discuss and put each event into its correct } \\
\text { category of dimension of cooperation in ASEAN. } \\
\text { T may facilitate the discussion process. }\end{array}$ & Group \\
\hline Report & $\begin{array}{l}\text { Ss tell the answer to } \\
\text { the class }\end{array}$ & $\begin{array}{l}\text { Ss report to class. Other Ss listen and note the } \\
\text { differences from their own group's answer. } \\
\text { T provides feedbacks. }\end{array}$ & Whole Class \\
\hline Task 2 & Ss give a presentation & $\begin{array}{l}\text { Ss give a presentation on the significance of the } \\
\text { events on ASEAN cooperation. }\end{array}$ & Group \\
\hline Planning & $\begin{array}{l}\text { Ss find facts in the } \\
\text { reading articles to } \\
\text { support main idea }\end{array}$ & $\begin{array}{l}\text { Ss give a presentation on the significance of the } \\
\text { events on ASEAN cooperation. }\end{array}$ & Group \\
\hline Report & $\begin{array}{l}\text { Ss present in front of } \\
\text { class }\end{array}$ & $\begin{array}{l}\text { Ss give presentation on the significance of the } \\
\text { events to ASEAN and why the dimension of } \\
\text { cooperation is indicative of ASEAN's achievement. } \\
\text { T provides feedbacks. }\end{array}$ & Whole class \\
\hline $\begin{array}{l}\text { Language } \\
\text { Focus } \\
\text { Analysis1 } \\
\end{array}$ & $\begin{array}{l}\text { Ss analyze words } \\
\text { to describe events } \\
\text { (declaration, etc.) }\end{array}$ & $\begin{array}{l}\text { Ss choose key events and related words. } \\
\text { T may give feedback. }\end{array}$ & Group \\
\hline Analysis 2 & $\begin{array}{l}\text { Ss analyze words } \\
\text { to describe area of } \\
\text { cooperation }\end{array}$ & $\begin{array}{l}\text { Ss may develop synonyms to express the idea on } \\
\text { the contribution of ASEAN to the field. } \\
\text { T may give feedback. }\end{array}$ & Group \\
\hline Practice 1 & $\begin{array}{l}\text { Ss practice writing } \\
\text { skills }\end{array}$ & $\begin{array}{l}\text { Using the synonyms, Ss develop a topic sentence } \\
\text { on the contribution of ASEAN to a particular area } \\
\text { to replace the model sentence that T gave them in } \\
\text { the Activity } 1 \text {. }\end{array}$ & Group \\
\hline
\end{tabular}

